\title{
What Paradigms and What For?
}

\author{
Jesús Fernández-Domínguez, Alexandra Bagasheva, and \\ Cristina Lara-Clares
}

1

\section{Introduction}

The paradigmatic character of the interword relationships has been present from the very beginnings of morphology as a branch of linguistics. The models of ancient Greek and Latin, to take a classic example, "[...] project morphological analysis primarily upwards from the word, and treat the association of words with paradigms or other sets of forms as the most fundamental morphological task" (Blevins, 2003, p. 375). As was the received wisdom in these ancient grammatical traditions, paradigmatic relations were mostly identified among word forms or what we would call today morphosyntactic words. The paradigm case of a paradigm was the set of forms in which a word could appear. It goes without saying that morphology was understood as the study of syntactically conditioned and appropriate forms.

\section{$2 \quad$ How Paradigmatic Is Derivational Morphology?}

More than one century after the appearance of de Saussure (1916), it may seem increasingly difficult to detect areas of modern linguistics that have not come under the influence of its postulates somehow or other. Even so, the crucial effect of this work remains outside the range of issues which periodically reemerge in the 2oth and 21st centuries. The debate surrounding word-formation paradigms is no exception, as it inexorably takes us back to de Saussure's (1916, p. 171) rapports associatifs: ${ }^{1}$

1 [Outside discourse, the words that have something in common are associated in the memory, and so groups are formed within which very diverse relations rule. Thus, the word enseignement will unconsciously arise in front of the mind a host of other words (enseigner, renseigner, etc., or armement, changement, etc., or éducation, apprentissage); for one reason or another, they all have something in common. Our translation] 
[E]n dehors du discours, les mots offrant quelque chose de commun s'associent dans la mémoire, et il se forme ainsi des groupes au sein desquels règnent des rapports très divers. Ainsi le mot enseignement fera surgir inconsciemment devant l'esprit une foule d'autres mots (enseigner, renseigner, etc., ou bien armement, changement, etc., ou bien éducation, apprentissage); par un côté ou un autre, tous ont quelque chose de commun entre eux.

Several of these features have turned out to be essential for the concept of paradigm, for example the fact that it involves relations outside discourse (i.e., in absentia), or that speakers tend to memorise and homogenise paradigm slots. Despite the vagueness in the understanding of paradigmatic structures and the sporadic reticence towards their application beyond inflectional morphology (Carstairs-McCarthy, 1987), the above definition is proof that de Saussure does not automatically exclude word formation from the span of paradigmaticity. He, as a token, draws on a series of derivatives for exemplification: enseignement-enseigner-renseigner. De Saussure's description is in fact somehow loose and limits itself to stating that members of a paradigm will have something in common, although what this is exactly is left unsaid.

Several properties have been discussed in the literature as central to the notion of paradigm and, consequently, to its potential suitability for the description of word formation. The following subsections consider a number of prominent attributes of paradigmaticity with the aim of offering a panorama of partially settled as well as live issues on derivational morphology. This catalogue does not intend to be exhaustive, but hopes to address a number of pertinent questions, presented in order of ascending complexity, for the description of word-formation paradigms.

\subsection{Understanding Paradigms and Neighbouring Concepts}

Before considering their possible relevance as an object of study for inflection and word formation, it seems necessary to set the limits of the entities known as paradigms. Perhaps because of their wide use in linguistic theory, or because of language-specific limitations, decades of attempts have not sufficed for a unanimous definition. One basic feature of the paradigmatic axis of language is that, in contrast to the syntagmatic one, it is largely based on relatedness, i.e., the similarity or disparity of linguistic forms or meanings. In turn, it is essential to note that "[...] relatedness is a matter of degree" (van Marle, 1994, p. 2927),

The use of the term paradigm has been at least three-fold. While an original understanding of it is inevitably linked to de Saussure's (1916) associative 
relations (see $\$ 2$ ), paradigmaticity may also point to the nature of the organisation of lexemes in the lexicon: synonymy, homonymy, polysemy, hyponymy, partonymy, etc. A third sense refers to the lexical units with the potential to occupy the same lot in language structure which, as is well-known, typically happens in inflection. The following features have been claimed to characterise a paradigm (Bybee 1985; Carstairs-McCarthy 1987; Bauer 1997; Antoniová \& Štekauer 2015):

i) It is made up of morphologically related forms,

ii) it is made up of forms that, though semantically derived from the same base, display some meaning divergence,

iii) it presupposes a typical set of realisations that can be regularly realised from the base form,

iv) it stems from a base word, from which a variable number of other words are systematically predictable, and

v) it is restricted to affixation.

This catalogue is purposefully broad with the goal of facilitating a joint treatment of inflection and derivation, even if these features materialise differently for each branch of morphology; let us not forget that inflectional paradigms and derivational paradigms are types of paradigms. Thus, if applied to inflection, criterion i) is taken to mean that the members of a paradigm should be formally related, as in the present indicative of Latin, where the roots (laud-, hab-, leg-) are common to all slots:

TABLE 1.1 An inflectional paradigm of Latin

\begin{tabular}{|c|c|c|c|c|}
\hline 1st p. & singular & laudo & habeo & lego \\
\hline 2nd $\mathrm{p}$. & & laudas & habes & legis \\
\hline 3 rd p. & & laudat & habet & legit \\
\hline 1st p. & plural & laudamus & habemus & legimus \\
\hline 2nd p. & & laudatis & habetis & legitis \\
\hline 3 rd p. & & laudant & habent & legunt \\
\hline
\end{tabular}

This notwithstanding, formal relatedness is far from a hard-and-fast rule even in inflection, as evidenced by the numerous instances of suppletion found across languages, e.g., go-went in opposition to call-called, followfollowed, work-worked, etc. in the expression of PRESENT-PAST in English (Veselinova, 2006). Series like this show how, in spite of formal disparity, suppletive units effectively fill in paradigm slots, which substantiates the idea that meaning, rather than form, is the decisive factor for the structuring of 
paradigms (Bauer, 2017). The application of criterion i) to word formation has far-reaching consequences which are discussed separately in $§ 2.3$.

Criterion ii) has to do with the semantic connection between the lexical base and all other forms in the paradigm, which must be close enough so as to set up a network. Observance of this condition in inflection can be confirmed by contrasting forms like laudo, laudas, laudat, laudamus, laudatis, and laudant, which share the core of their meaning (here, present indicative of LAUDĀRE 'to praise') and are thus grammatically connected to each other. In the case of derivation, the meaning in common across paradigm members is that of the root, but the added meaning in each particular form will depend on the morphological process involved. For instance, perform is the starting point of a derivational paradigm where a range of semantic roles are possible: performing ${ }_{\mathrm{N}}$ (ACTION), performance (PROCESS), underperform (DIMINUTION), performer (AGENT), performable (QUALITY), etc. While the meaning expressed in the present of indicative is clearly inflectional and that in AGENT is clearly derivational, semantic distance is a thorny issue in the discussion of the inflectionderivation continuum, with cases like the inflectional vs. derivational status of -ly (see Giegerich, 2012). To what extent such semantic divergence concerns more inflection or derivation is once more a consequence of the debate on split morphology, beyond the scope of this article (see §3).

\subsection{Gaps and Predictability-Actual vs. Potential Words}

Potential words have been of relevance to morphologists ever since Aronoff's (1976) precept that "[...] the simplest task of a morphology [...] is the enumeration of the class of possible words of a language" (pp. 17-18). Aronoff's challenging statement led to the demarcation between actual, possible and potential words, the effects of which have been subsequently felt variously in word-formation research (Aronoff, 1983; Bybee, 1985, p. 85; Bauer, 2001, pp. 3443; Rainer, 2012). In the field of paradigmaticity, Horecký, Buzássyová, and Bosák maintained already in 1989 that "[...] new complex words do not come into existence as isolated units but rather as complete paradigms" (p. 42; see Stekauer, 2014, p. 36o). The question therefore is how to cope with the empty spaces in those paradigms.

Potential words have been pointed out as a fundamental difference between inflection and derivation: paradigmatic gaps or defective paradigms are relatively anomalous in inflection (note the expressive terminology) given the obligatory nature of inflection, as proved by the fact that these gaps will be filled by a non-related stem if a regular form is unavailable. The circumstances are different in derivation since, not being grammatically compulsory, its application cannot be anticipated and hence gaps are not the exception (Štekauer, 2014, p. 357). Gaps in derivation are not unknown to word formationists, who 
have studied the phenomenon by considering phonological, morphological and semantic factors (Raffelsiefen, 1996; Kjellmer, 200o; Stump, 2018). Precisely due to the very nature of word formation, the suitability of the qualifier defective may be called into question as a descriptor for word-formation paradigms. Table 1.2 exemplifies two different types of gap filling:

TABLE 1.2 A gap in a derivational paradigm

\begin{tabular}{lll}
\hline root & 1st order & 2nd order \\
\hline $\begin{array}{lll}\text { capital } \\
\text { character }\end{array}$ & $\begin{array}{l}\text { capitalist } \\
\text { capitalistic } \\
\text { characteristic }\end{array}$ \\
\hline
\end{tabular}

In the first paradigm, capital is the lexical base upon which capitalist and capitalistic are generated and, because the three slots are filled, it is possible to sequentially follow the derivational chain. The opposite is true for the second paradigm where, due to the non-existence of *characterist, a gap emerges in the first order of derivation, with the consequence that the root (character) cannot be morphologically linked to the second order (characteristic). This goes against the principle of uniformity of paradigms. Several ways out have been proposed in this respect, one of which is a diachronic reanalysis whereby characteristic is not derived by -ist and then -ic, but by -istic right away. This proposal gets around the problem by turning a two-order paradigm into a oneorder one, and is labelled the Full Reanalysis Hypothesis (Stump, 2018, pp. 4-5). One consequence of such reanalysis is an adjustment of the paradigm's internal configuration in order to accommodate two forms where there were three. At least three options exist for this new configuration:

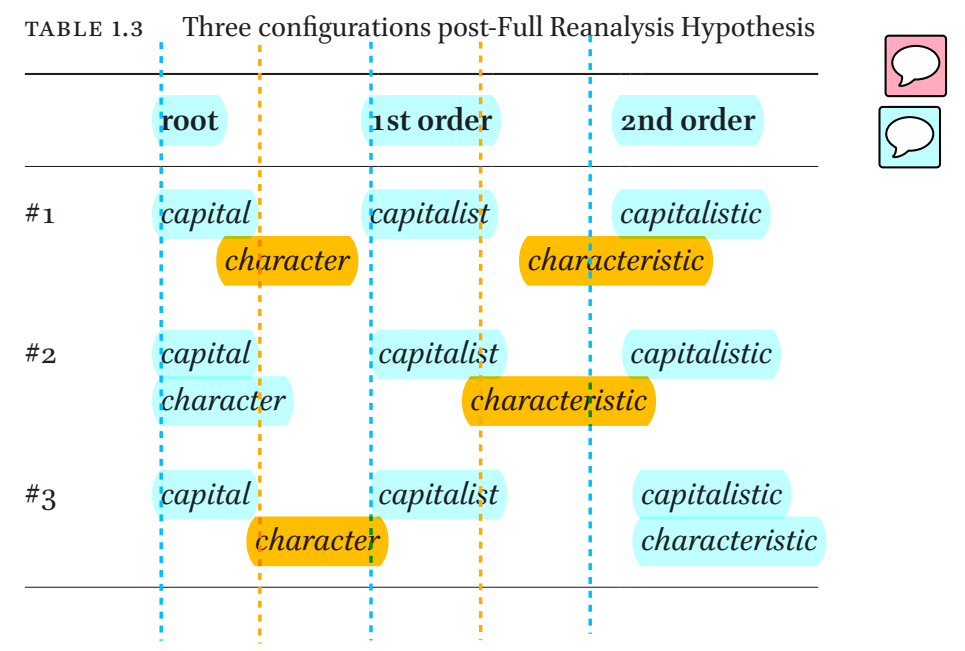


Reanalysis \# $\#_{1}$ implies a redistribution of the paradigm's space, which is evenly split for each of the two forms. The major problem with this analysis is that the implicit paradigmatic structure is not parallel to that of paradigms like capital-capitalist-capitalistic, and this contradicts the principle of structural equivalence across paradigms. Reanalysis \# 1 must hence be disregarded. The alternative of reanalyses $\#_{2}$ and $\#_{3}$ is to align one of the forms character and characteristic with one of the three forms in the other paradigm, while the other form (character or characteristic) is aligned with two forms simultaneously. In reanalysis \#2, for example, character and capital are equated as roots, and characteristic assumes all further derivation, in this case through -istic, which would correspond to -ist and -ic for capitalistic. In reanalysis \# 3 , the root of one paradigm (character) corresponds to the root and the first order of derivation in the other (capital and capitalist), and the second orders of derivation are equivalent in both. However, reanalysis \# 3 means that an already suffixed unit (capitalist) is paralleled to a root (character), and that a unit of a second order (capitalistic) is paralleled with a unit of one of a first order (characteristic), with morphosemantic inconsistencies as a result.

Albeit with different implications, the three possibilities in Table 1.3 share a reduction of the number of slots from three to two, thus generating a minimal derivational paradigm. Because the only previous gap in the paradigm is eliminated and the remaining slots are full, Table 1.3 represents a fully saturated paradigm, which means that there is no room for new coinages in it. Lexical gaps are in fact potential naming needs. These factors all make it advisable to accept paradigmatic gaps, as in Table 1.2, rather than to avoid them at the expense of reducing the number of slots (Table 1.3). The (non-)existence of lexical gaps is synchronically circumstantial and inherent to derivation, and clearing them off paradigms would exert the undesirable effect of precluding potential words, in turn restraining derivational morphology from its main purpose: lexical creation. This is precisely Bauer's (1997) position when he maintains that "[...] the availability of the slots [is] more important for the paradigm than the forms which fill them" (p. 253; Dammel \& Kempf, 2018, pp. 8o-81). The above seems good reason to assert that lexical gaps are perhaps not a prerequisite, but a major boost for morphological productivity, since they favour the use of morphological processes to meet that need and instigate phenomena like analogy, morphological competition or blocking, among others.

Gaps play a key role also in relation to the predictability of paradigm members, since predictability comes into play especially for empty slots. The study of predictability in word formation is not new and has been approached from various perspectives, e.g., onomasiological (Štekauer, 2005), psycholinguistic (Gagné, Marchak, \& Spalding, 2010) and, more recently, in relation to derivational paradigms explicitly (Bonami \& Strnadová, 2019). In a nutshell, the 
debate concerns the degree to which the forms and meanings of the units that occupy the slots in a paradigm can be successfully anticipated. Contrary to widespread belief, it has been shown that cell predictability is as probable in word formation as it is in inflection, even if paradigmatic gaps are more frequent in the former (Bauer 1997; Antoniová \& Štekauer, 2015).

\subsection{Usefulness of Paradigms in Word Formation}

One central matter that is at the same time a source of disagreement is which morphological processes should be a part of paradigmatic word formation. Viewpoints have ranged in their degree of restrictiveness. If one particular goal is to put derivation on the same level as inflection, then only affixation should probably be involved in the constitution of paradigms, as it is the vehicle of expression of inflection (e.g., Table 1.1; Matthews, 1974; Pounder, 2000, p. 47; ten Hacken, 2014). The array of morphological operations available for word formation, by contrast, is considerably broader and, with slight variation across languages, it includes affixation, back-formation, blending, clipping, compounding, conversion, or parasynthesis. As it may be manifest, limiting the span of derivational paradigms to affixation means dismissing the lexical output of not few processes, a central decision because these processes generate the bulk of complex words in some languages (Štekauer, Valera, \& Körtvélyessy, 2012).

Štekauer (2014) describes two conceptions of derivational paradigms in this respect. The first conception is a narrow one where only affixation participates and where the result is a paradigm with systematic, regular and predictable relationships, akin to an inflectional one, at the cost of limiting the number of potential words. This is the most adequate view, in Štekauer's opinion. The second conception is a broad one which welcomes all the complex words that are produced by word-formation processes with a common stem, which thus increases the slots for potential words but is "[...] paradigmatically vacuous because it does not lead to a predictable and regularly organized system of complex words" (2014, p. 369).

The involvement of different morphological processes in derivational paradigms has been treated differently in the specialised literature. Unsurprisingly, virtually every survey into word-formation paradigms has studied prefixation or suffixation in one way or another, and not few have strictly focused on these processes (e.g., Fehringer, 2003; Beecher, 2004; Janssen, 2005; Booij \& Lieber, 2014; Antoniová \& Štekauer, 2015; Boyé \& Schalchli, 2016; Gaeta \& Angster, 2018; Stump, 2018; among many others). It is less frequent to find surveys of paradigmaticity into other morphological process. After affixation, compounding has been the secondary centre of attention for specialists, some giving it full consideration and others dealing with it only in passing (van Marle, 
1985; Bybee, 1985, pp. 105-109; Stump, 1991; Bauer, 1997, p. 253; Pounder, 200o, pp. 82-95; Booij, 2008; Dammel \& Kempf, 2018). Among these, van Marle's (1985, pp. 16-21, 121) contribution is noteworthy because, being a pioneer in the paradigmatic dimension of derivation, he already analyses the behaviour of compounds in this area. Bagasheva (2015) also discusses the advantages of word-formation paradigms for a uniform analysis of compound verbs in that they are created by a miscellany of processes, namely, compounding proper, conversion and back-formation but constitute a uniform lexical class of words with identical morphosyntactic properties.

Conversion is dealt with generally in van Marle (1985), although this process is not the principal focus of the monograph. The key to the inclusion/exclusion of conversion in paradigmatic word formation is that converted units do not constitute for van Marle a morphological category, as the formal characteristics that they share come from their behaviour, namely, their positioning in the sentence as members of a word-class different from their original one. Units created by conversion would not therefore meet the formal criteria of word formation. Van Marle (1985) also claims that these units are not complex words from a semantic point of view either because their meaning similarities have more to do with their categorial value: "[ $\mathrm{t}]$ he semantic characteristics that the nouns at issue have in common, to put it differently, only result from the fact that they are nouns" (pp. 144-145). The opposite is found in Becker (1993), where noun>verb and verb $>$ noun conversion are discussed on a par with other concatenative morphological processes and are presented as a type of cross-formation, that is, a word-formation rule which is equally productive in both directions. Conversion is regarded as a part of derivational paradigms in this and other works (Antoniová, 2016; Bonami \& Strnadová, 2019; Dammel \& Kempf, 2018).

Traditionally of lesser importance in the catalogue of word-formation processes, back-formation was first studied from a paradigmatic perspective in Becker (1993), where it is shown to be of paramount relevance due to its unconventional directionality of derivation. Becker (1993) discusses matters related to the diachronic and synchronic facets of back-formation, as well as the semantic and formal dependence between base and derivative. His main conclusion is that back-formation is not only relevant synchronically, but also fully pertinent for a paradigmatic theory because, just as there exists a morphological rule for pairs like work > worker, another valid rule will be used for burglar > burgle. In his words, "[b] esides differences in productivity and in the morphophonological operations (affixation vs. affix subtraction), they are of the same rule type" (Becker, 1993, p. 7; see Booij, 2012, pp. 40-41; Štekauer, 2015). 
Remarkably enough, no in-depth study has been carried out to the best of our knowledge on the role of neoclassical compounding and combining forms in word-formation paradigms, and neither on the processes of lexical blending, acronymy, clipping or eponymy.

\subsection{Theoretical Constructs or Entities with Psychological Reality for Speakers}

Though not explicitly addressed as a null hypothesis, the existence of paradigms as psychologically real network-like structures in the mental lexicons of speakers has been amply tested in psycholinguistic experiments (see Libben \& Jarema, 2004). In essence, psycholinguistic research on family size effects (see Bertram, Baayen, \& Schreuder, 200o) and the nature of the relationship between constituents in compounds (e.g., Gagné \& Shoben, 2002) tacitly presume the existence of some memory guiding principle which facilitate speakers in the processing of complex words. It might be suggested that all the principles being tested are different paradigmatic dimensions as the ones Bauer (2017) identifies for the variety of paradigms. As can be gleaned from Gagné et al. (2010), meaning predictability is a central issue in psycholinguistic research; meanwhile predictability (see $\$ 2.2$ ) is a golden standard desideratum for a paradigm. The debate over relational (thematic) vs. attributive relations in root nominal compounds (see for example Estes, Golonka, \& Jones, 2011 and Estes, 2003) illustrates different possible meaning-based dimensions of paradigmatic structures.

The very concept of second order schemas (as defined by Booij \& Masini, 2015, p. 47) seems to fit in degrees of granularity and abstractness with the idea of local paradigms. "[V]iolation of Fregean compositionality can be accounted for by means of 'second order schemas', i.e., sets of two or more paradigmatically related constructional schemas" and these, being schemas, are psychological in nature.

Even though the psychological reality of paradigms has not been directly tested, it is far from mere conjecture. We are a long way from gaining any direct insight as to the nature of paradigms in the mind, but research in this direction can more clearly focus on testing hypotheses about dimensions that generate and maintain paradigms in word formation.

\subsection{Typology of Word-Formation Paradigms}

The question of the possibility of different entities being recognised as paradigms is still open. Bonami (2017) identifies two ways in which paradigmaticity can figure prominently in word formation. On the one hand it could be understood 
as "paradigmatic relations between words by opposition to syntagmatic relations between words and word parts" (or Štekauer's (2014) broad understanding of a paradigm). On the other, "it may literally extend analytic strategies originally conceived for the study of inflectional paradigms to the domain of wordformation" (Bonami, 2017; or the narrow definition of a word-formation paradigm provided by Štekauer, 2014). The first conception not only postulates a difference in the nature of paradigms in inflection morphology and word formation, but also posits a different principle for word-formation paradigms.

In a similar vein of reasoning, Spencer (2017) argues that paradigms in inflection and word formation are "logically distinct types of relation, only superficially similar".

Both broad views described above allow for a basic difference between inflectional and word-formation paradigms and, more importantly, both positions presume a diversity of paradigm types within word formation. Spencer (2017) distinguishes "an inflectional-type paradigm, Пi, from a derivationaltype paradigm, $\Pi d$ " with none of the properties shared by the two types. The differentiation goes on further to the recognition of a "chain- $\Pi d$ " and "'radial-Пd". From the brief expounding of different versions of understanding paradigmaticity, it transpires that the diversity of types of paradigms is the rule, rather than the exception.

This diversity, at least in the field of word formation, is recognised by Bauer (2017) with the following different kinds of paradigms: a paradigm of FUNCTIONS; paradigms of MORPHOLOGICAL MATERIAL; the paradigm of LEXICAL MATERIAL; a conjugation class (which fits the criteria for a paradigm); a word class (but again it is a paradigm); a paradigm of PREDICTABLE RELATIONsHips (e.g., 'made of'), etc. (spelling as in the original). Bauer discusses the

AQ1 following dimensions of variability among paradigm types: PREDICTABILITY, CLOSENESS/OPENNESS OF THE SET; EXTENSIVITY; MEMBERSHIP (one relevant item or more than one relevant item); and SPECIFICITY. The common property of all these variable structures is relatedness on the basis of a conspicuous feature. Settling the controversy with the nature of paradigms (in word formation) requires that all possible features of relatedness and any inherent hierarchy thereof be exhaustively described, which might turn out to be unattainable as the concept of prime number is for a mouse (see Piattelli-Palmarini, 200o). It might be that (at least some types of) paradigms in word formation turn out to be an "irreducible component of cognition" (Piattelli-Palmarini, 200o, p. 358). The fact that at present scholars cannot agree on the nature and typology of (word-formation) paradigms does not in any way undermine their psychological reality as matrixes aiding speakers in operation with the architecture of language. 
Approaching the span of morphological paradigms as an either-or choice between inflection and derivation has underlying theoretical implications. Bauer (1997, pp. 243-244) is conclusive: restricting paradigms to the region of inflectional morphology implicitly means endorsing the existence of a split morphology, which sees inflection and derivation as independent grammar modules (see Anderson, 1982; Plank, 1994; ten Hacken, 2014). In contrast, allowing for (some kind of) paradigms in derivation involves perceiving a continuum between inflection and derivation, with more and less prototypical paradigms occurring along the cline depending on their features.

Reservations over the existence of paradigms in word formation have most often been voiced regarding the alleged irregularity of derivational morphology. As opposed to inflection, derivation has been conventionally described as full of exceptions that are caused by phenomena like morphological competition (van Marle, 1994, pp. 2929-2930; Plag, 1999; Bauer, 2009; Aronoff, 2016) or blocking (Rainer, 1988, 2016; Giegerich, 2001; cf. Kjellmer 200o, p. 224; Don AQ2 \& Lin, 2014), among others. This all results in paradigms which, at least from a purely formal point of view, are defective in nature because they very often lack slots for specific categories, which is rarer in inflection. An example is shown in (1), which shows lexemes for the role AGENT and would thus be a part of the paradigm for that semantic category:

(1) teach $>$ teacher, novel $>$ novelist, escape $>$ escapee, milk $>$ milkman,
spy $y_{\mathrm{V}}>$ spy
, express $>$ *expresser

Two facts should be differentiated in this respect, however. The first is that one and the same derivational affix is rarely applicable beyond its derivative scope (thus, teacher but *noveler, *escaper, *milker); the second fact is that the primary purpose of word formation is to express a given meaning (here, AGENT), and hence the form of derivatives is of secondary importance only. This is why the specific suffix (-er, -ist, -ee, etc.) is irrelevant as long as the new lexeme materializes. The same reason justifies why word-formation paradigms are relevant not only to affixation, but to any other morphological process that may coin a semantically appropriate lexeme, e.g., compounding (milkman) or conversion $\left(s p y_{\mathrm{N}}\right)$.

These facts aside, cases are not uncommon of unattested units, e.g., *expresser which, despite being potential words, currently represent gaps in the paradigm (see Bauer, 1997, p. 245, Štekauer, 2014, p. 357, Gaeta \& Angster, 2018, pp. 5-6, Olsen 2019). 
For van Marle (1994), three characteristics shape the homogeneity of inflectional paradigms, namely that they

(a) share the same base,

(b) share a large number of properties, and

(c) their differences are relatively small.

As seems evident, extending the notion of paradigmaticity to derivation will be problematic if the above are taken as defining conditions, insofar as the systems of inflection and derivation are markedly different and direct correlation is improbable.

Following van Marle (1994), "[t]he only conclusion which is justified is that in derivation paradigmatic structure may manifest itself in a fundamentally different way from the way it does in inflection" (p. 2929). Again, it is suitable to go back to de Saussure, 1916 (p. 174):

Un terme donné est comme le centre d'une constellation, le point où convergent d'autres termes coordonnés, dont la somme est indéfinie. ${ }^{2}$

De Saussure's discussion certainly makes it clear that associative relations are more characteristically found in inflection, but nowhere in it do we find an explicit exclusion of derivation. In fact, just as it is explained that "[...] pour la conscience des sujets parlants le nominative n'est nullement le premier cas de la déclinaison, et les termes pourront surgir dans tel out el ordre selon l'occasion"3 (de Saussure, 1916, p. 715), the same principle may be extrapolated to the field of word formation. That is, that the lexeme expected to be the basis for derivation is not always attested first in actual language use. A case in point is that of back-formation, described by many as relevant diachronically only on the basis of the listing of the hypothetical lexical base (Becker, 1993; Štekauer, 2015).

\section{$4 \quad$ Description of the Volume}

As has been shown, a range of research questions have been recently addressed in relation to the paradigmatic nature of word formation, not all of which have received a satisfactory answer as of today. Unsettled matters include the

2 A given term is like the center of a constellation, the point where other coordinated terms converge, the sum of which is indefinite. [Our translation]

3 For the speaking subject, the nominative is not at all the first case of the declension, and the terms can arise in one or another order depending of the occasion. [Our translation] 
nature of paradigmatic relations in word formation and the lexicon; the interconnectedness between derivational families and paradigms; the constitutive characteristics of a word-formation paradigm; the degree of predictability that word-formation paradigms can display; the specificity of paradigms depending on the variety of recognised word-formation processes and patterns (if any); etc.

The growing interest for paradigmaticity in lexical morphology is evidenced not only by the quantity and quality of related publications, but also by the recent celebration of several thematic workshops specifically dedicated to the theory and applications of the concept of paradigm in word formation (more prominently derivation). The papers that are collected here were part of the workshop Revisiting Paradigms in Word-formation, hosted within the Word-Formation Theories III and Typology and Universals in Word-Formation IV Conference, held at Pavol Jozef Šafárik University (Košice, Slovakia) in June 2018. A wide audience gathered together there for the discussion of unsettled matters in the area of word-formation paradigms, some of which are a part of this volume.

The first contribution is authored by Alexandra Bagasheva, who discusses i) the nature of paradigmaticity (and paradigms) in word formation, ii) how paradigmaticity, motivation and analogy are related, and iii) the status of compound verbs in relation to the way compounds inform our understanding of the role of paradigms in word formation (and possibly the reverse). Bagasheva maintains that paradigms are psychologically real and that the inherent paradigmaticity of word-formation products and the role of analogy account for the growing number of compound verbs in English. Besides, it is claimed that the fact that parasynthetic adjectives rarely, if ever, function as motivating bases for compound verb derivation only strengthens the assumption of the pervasiveness of paradigms in word formation as sets of analogical products where the principle of relational priming operates.

Bernard Fradin (Chapter $\stackrel{2}{\mathbf{2}}$ ) explores whether derivational paradigms can be useful to make predictions about possible lexemes in a way similar to the predictive role played by inflectional paradigms in inflection. Using an extended view of the notion of paradigm proposed by Bonami and Strnadová (2019), it is assumed that a paradigm is a collection of morphological families structured by the same system of oppositions of content, whose nature can be either morphosyntactic (inflection) or morphosemantic (derivation) and which has a predictive potential provided the elements that belong to the morphological families are properly aligned. The chapter deals with the domain of relevance and the organization of derivational paradigms and discusses existing proposals, namely those made by Roché (2017a, 2017b), and concludes that 
it is necessary to account for the variety of derivational paradigms in order to make them more efficient as descriptive devices.

In the chapter, Petr Kos argues against the consideration of word nests as paradigmatic. The chapter applies Dokulil's (1962) major onomasiological categories, i.e., the modificational, the transpositional and the mutational, to distinguish regular and predictable relations of paradigms from an open system of complex words related only by a common stem. The mutational category, Kos argues, is not canonically paradigmatic because i) there is a significant shift in meaning between the original stem and the resulting derivation, ii) the existence of naming units depends on the naming of the extralinguistic reality and, thus, it is difficult to think of pre-existing cells which would be filled by these new naming units, and iii) the predictability of a form lowers when the decision of which (probably synonymous) suffix will be used depends on the coiner. The chapter concludes, thus, that only the modificational and the transpositional categories comply with the features of paradigmaticity put forward by Bauer (1997).

Lior Laks and Faten Yousef (Chapter 4) examine the correlation between derivational paradigms and doublet formation in Palestinian Arabic and investigate the role of paradigms in morphological change. They argue that morphological change takes place in order to achieve both structural and semantic transparency in paradigms. Their exploration of cases of variation reveals that only $\mathrm{CiCeC}$ verbs with transitive alternates in $\mathrm{CaCCaC}$ have $\mathrm{tCaCCaC}$ doublets. The $\mathrm{CaCCaC}-t \mathrm{CaCC} a \mathrm{C}$ paradigm is found to be the most productive transitiveto-intransitive paradigm, and they claim that $\mathrm{CiCe}$ intransitive verbs that are related to $\mathrm{CaCCaC}$ transitive verbs change their form, adhering to the most common paradigm. The chapter thus shows that words are more likely to undergo morphological change when they are part of a derivational paradigm, as the morphological change establishes more uniform paradigms.

Eleonora Litta and Marco Budassi (Chapter 5) aim at determining the main requirements for the physical representation of a derivational paradigm through data from the Word Formation Latin (WFL) lexicon (Litta, Passarotti, \& Culy, 2016). Considering the problems in the representation of derivational families in WFL, paradigms are here represented in a tabular form so as to adopt aspects of Construction Morphology (CxM, Booij, 2012), which highlights the importance of the 'cell' as a meaningful location for lexemes that can be filled to add morphological and semantic information. This chapter also assesses a number of concepts from CxM with regard to their validity for a description of the function of Latin paradigm cells throughout time and space.

The chapter is authored by Jan Radimský, who reviews a number of types of paradigmatic relations, namely word families, word series, paradigms and paradigmatic systems, as defined in Boyé and Schalchi (2016) and Bauer 
(2017), and discusses their relevance for an analysis of compounding. Radimský argues that the study of compounds within a paradigmatic approach allows for an account of a number of phenomena that are challenging for rule-based approaches. The paradigmatic approach is, according to the author, so closely related to CxM that "paradigms" and "constructions" seem to actually be two different names for the same concept, even though some essential differences set the two frameworks apart. This chapter underlines the relevance of the concept of paradigm for the study of compounding and argues that a paradigmatic approach may be an appropriate answer for issues concerning both learned and native Romance Noun-Noun compounds.

Chapter 7 , by José Antonio Sánchez Fajardo and Elizaveta Tarasova, deals with Adj+ie/y nominalisations. Specifically, it focuses on the i) amount of polysemy of deadjectival -ie diminutives and ii) the semantic convergence of the output units whose formation and semantic content is driven by an ellipsed noun, an adjectival base (colour/origin) and the suffix -ie/y. The -ie/y units in this chapter are collected from dictionaries (Ayto, 1998; Thorne, 2014; MWD11; OED3), and examples of their use are extracted from the Now Corpus. This chapter analyses the morphosemantic features by using the onomasiological approach to word formation (Štekauer, 2005), and several relevant principles of Construction Grammar. The results suggest a gradient regularity and predictability in the formation of Adj+ie/y nominalisations and they demonstrate a correlation between the semantic features of these 'diminutive' constructs and their impact on an endearment-pejoration scale.

Díaz-Negrillo (Chapter \&) explores neoclassical compounds and their morphologically-related lexical formations through a word-based treatment. The suitability of a paradigm-based approach is tested, with a focus on [X-scope] formations. Over 46o formations extracted using OED data are classified into 14 semantic categories which may set the base for the configuration of a set of categories for paradigm-based accounts of neo-classical compounds. Issues like paradigmatic pressure, competition or analogy are discussed in this chapter, which concludes that a word-based approach to neoclassical word formation has a number of advantages compared to morpheme-based approaches.

\section{References}

Anderson, S. R. (1982). Where's morphology? Linguistic Inquiry, 13, 571-612.

Antoniová, V. (2016). Derivational paradigm —is there any? A contrastive research.

SKASE Journal of Theoretical Linguistics, 13(2), 91-105. Available at: http://www .skase.sk/Volumes/JTL32/pdf_doc/o5.pdf [Accessed 28 September, 2018]. 
Antoniová, V., \& Štekauer, P. (2015). Derivational paradigms within selected conceptual fields-Contrastive research. Facta Universitatis, Series: Linguistics and Literature, $13(2), 61-75$.

Aronoff, M. (1976). Word-formation in generative grammar. Cambridge, MA: MIT Press. Aronoff, M. (1983). Potential words, actual words, productivity and frequency. Proceedings of the 13th International Congress of Linguists, Tokyo, 163-171.

Aronoff, M. (2016). Competition and the lexicon. In A. Elia, C. Iacobino \& M. Voghera (Eds.), Livelli di Analisi e fenomeni di interfaccia. Atti del XLVII congresso internazionale della società di linguistica italiana (pp. 39-52). Roma: Bulzoni.

Ayto, J. (1998). Oxford dictionary of slang. Oxford: Oxford University Press.

Bagasheva, A. (2015). Paradigmatic word-formation, metonymy and compound verbs in English and Bulgarian. In J. Audring, N. Koutsoukos, F. Masini \& I. Raffaelli (Eds.), Morphology and semantics-MMMg on-line Proceedings, 1-11. Available at: http://www.lilec.it/mmm/wp/wp-content/uploads/2015/o2/2276-3980-1-SM.pdf [Accessed 10 January, 2018].

Bauer, L. (1997). Derivational paradigms. In G. Booij \& J. van Marle (Eds.), Yearbook of morphology 1996 (pp. 243-256). Dordrecht: Kluwer. Do I: 10.1007/978-94-o17-3718-o_13 [Accessed 10 January, 2018].

Bauer, L. (2001). Morphological productivity. Cambridge: Cambridge University Press.

Bauer, L. (2009). Competition in English word-formation. In A. van Kemenade, B. Los (Eds.), The handbook of the history of English (pp. 177-198). Malden, MA: Blackwell.

Bauer, L. (2017). Notions of paradigm and their value in word-formation. Paper delivered at ParadigMo 2017: First Workshop on Paradigmatic Word-formation Modeling, Toulouse, 19-20 June 2017 .

Becker, T. (1993). Back-formation, cross-formation, and 'bracketing paradoxes' in paradigmatic morphology. In G. Booij \& J. van Marle (Eds.), Yearbook of Morphology 1993 (pp. 1-25). Dordrecht: Kluwer.

Beecher, H. (2004). Derivational paradigm in word formation. Available at http:// citeseerx.ist.psu.edu/viewdoc/download?doi=10.1.1.94.9071\&rep=rep1\&type=pdf [Accessed 1o September, 2018].

Bertram, R., Baayen, R. H., \& Schreuder, R. (2000). Effects of family size for complex words. Journal of Memory and Language, 42, 390-405.

Blevins, J. P. (2013). Word-based morphology from Aristotle to modern WP (Word and Paradigm models). In K. Allan (Ed.), The Oxford handbook of the history of linguistics (pp. 375-396). Oxford: Oxford University Press.

Bonami, O. (2017). Predictability in inflection and word-formation. Paper delivered at ParadigMo 2017: First Workshop on Paradigmatic Word-formation Modeling, Toulouse, 19-20 June 2017 .

Bonami, O., \& Strnadová, J. (2019). Paradigm structure and predictability in derivational morphology. Morphology, 1-31. DOI: 10.1007/s11525-018-9322-6 [Accessed 24 September, 2018]. 
Booij, G. (1997). Autonomous morphology and paradigmatic relations. In G. Booij \& J. van Marle (Eds.), Yearbook of Morphology 1996 (pp. 35-53). Dordrecht: Kluwer.

Booij, G. (2008). Paradigmatic morphology. In B. Fradin \& G. Dal (Eds.), La raison morphologique. Hommage á la mémoire de Danielle Corbin (pp. 29-38). Amsterdam \& Philadelphia, PI: John Benjamins.

Booij, G. (2012). The grammar of words. An introduction to linguistic morphology. Oxford: Oxford University Press.

Booij, G., \& Lieber, R. (2014). On the paradigmatic nature of affixal semantics in English and Dutch. Linguistics, 42(2), 327-357.

Booij, G., \& Masini, F. (2015). The role of second order schemas in the construction of complex words. In L. Bauer, L. Körtvélyessy \& P. Štekauer (Eds.), Semantics of complex words (pp. 47-66). Berlin: Springer.

Boyé, G., \& Schalchli, G. (2016). The status of paradigm. In A. Hippisley \& G. Stump (Eds.), The Cambridge handbook of morphology (pp. 206-234). Cambridge: Cambridge University Press.

Bybee, J. (1985). Morphology. A study of the relation between meaning and form. Amsterdam \& Philadelphia, PI: John Benjamins.

Caerdenfors, P. (1999). Some tenets of cognitive semantics. In J. Allwood \& P. Gaerdenfors (Eds.), Cognitive semantics: Meaning and cognition (pp. 19-36). Amsterdam: John Benjamins.

Carstairs-McCarthy, A. (1987). Allomorphy in inflection. London: Croom Helm.

Carstairs-McCarthy, A. (2010). The evolution of morphology. Oxford: Oxford University Press.

Cruse, A. (2000). Meaning in language. An introduction to semantics and pragmatics. Oxford: Oxford University Press.

Dammel, A., \& Kempf, L. (2018). Paradigmatic relationships in German action noun formation. Zeitschrift für Wortbildung / Journal of Word-Formation, 2, 52-85. Available at: https://www.peterlang.com/fileasset/Journals/ZWJW201802_book.pdf [Accessed 24 January, 2019],

de Saussure, F. (1916). Cours de linguistique générale. Lausanne-Paris: Payot.

Dokulil, M. (1962). Tvoření slov v češtině 1, Teorie odvozování slov. Praha: Nakladatelství Československé akademie věd.

Don, J., \& Lin, J. (2014). A syntagmatic analysis of 'paradigmatic' morphology. In R. Kager, J. Grijzenhout \& K. Sebregts (Eds.), Where the principles fail: a festschrift for Wim Zonneveld on the occasion of his 64th birthday (pp. 29-40). Utrecht: Utrecht Institute of Linguistics отs.

Estes, Z. (2003). Attributive and relational processes in nominal combination. Journal of Memory and Language, 48, 304-319. DoI: 10.1016/So749-596X(o2)00507-7.

Estes, Z., Golonka, S., \& Jones, L. (2011). Thematic thinking: the apprehension and consequences of thematic relations. In B. Ross (Ed.), Psychology of Learning and Motivation (Vol. 54, pp. 249-294). Burlington: Academic Press. 
Fehringer, C. (2003). Morphological 'gangs': Constraints on paradigmatic relations in analogical change. In G. Booij \& J. van Marle (Eds.), Yearbook of Morphology 2003 (pp. 249-272). Dordrecht: Kluwer.

Gaeta, L., \& Angster, M. (2018). Stripping paradigmatic relations of out the syntax. Morphology, 1-22. DOI: 10.1007/s11525-018-9326-2 [Accessed 24 September, 2018].

Gagné, C. L., \& Shoben, E. (2002). Priming relations in ambiguous noun noun combinations. Memory and Cognition, 30(4), 637-646.

Gagné, C. L., Marchak K. A., \& Spalding, T. L. (2010). Meaning predictability and compound interpretation: A psycholinguistic investigation. Word Structure, 3, 234-251.

Giegerich, H. J. (2001). Blocking and the Elsewhere Condition: Lexical morphology and the speaker. Transactions of the Philological Society, 99(2), 65-98.

Giegerich, H. J. (2012). The morphology of $-l y$ and the categorial status of 'adverbs' in English. English Language and Linguistics, 16(3), 341-359.

Horecký, J., Buzássyová, K. \&, Bosák, J. (1989). Dynamika slovnej zásoby súčasnej slovenčiny. Bratislava: Veda.

Janssen, M. (2005). Between inflection and derivation: Paradigmatic lexical functions in morphological databases. In J. D. Apresjan \& L. L. Iomdin (Eds.), East-West Encounter: Second International Conference on Meaning and Text Theory (pp. 187196). Moscow: Slavic Culture Languages.

Kjellmer, G. (2000). Potential words. Word, 51(2), 205-228. DoI: 10.1080/00437956 .2000 .11432501 .

Libben, G., \& Jarema, G. (2004). Conceptions and questions concerning morphological processing. Brain and Language, 90, 2-8. DOI: 10.1016/j.bandl.2003.12.005.

Litta, E., Passarotti, $\mathrm{M}_{\mathbf{2}} \&$, Ruffolo, P. (2017). Node formation: Using networks to inspect productivity in affixal derivation in Classical Latin. In A. Antonacopoulos \& M. Büchler (Eds.), Proceedings of the 2nd International Conference on Digital Access to Textual Cultural Heritage (DATeCH2017) (pp. 103-108). New York, NY: ACM.

Matthews, P. H. (1974). Morphology. An introduction to the theory of word-structure. Cambridge: Cambridge University Press.

MWD11: Merriam-Webster dictionary online, 11th edition, Merriam-Webster, Inc. https:// www.merriam-webster.com [Accessed 1o December 2017].

Now: Davies, M. (2013). Corpus of News on the Web: $3^{+}$billion words from 20 countries, updated every day. http://corpus.byu.edu/now/ [Accessed 30 August, 2018].

oED3: Oxford English Dictionary, 3rd edition, Oxford University Press. https://oed.com [Accessed 14 December, 2017].

Olsen, S. (2019). The relatedness of meaning in derivational patterns. In J. Audring, N. Koutsoukos \& C. Manouilidou (Eds.), MMM12 Online proceedings (pp. 64-76). https://mmm.library.upatras.gr/mmm/article/view/3250/3510 [Accessed 26 February, 2020]. 
Piattelli-Palmarini, M. (2000). An "irreducible" component of cognition. In R. Singh, C. Krimbas, D. Paul \& J. Beatty (Eds.), Thinking about evolution: Historical, philosophical, and political perspectives (pp. 353-376). Cambridge: Cambridge University Press.

Plag, I. (1999). Morphological productivity: Structural constraints in English derivation. Berlin: Mouton De Gruyter.

Plank, F. (1994). Inflection and derivation. In R. E. Asher (Ed.), The encyclopedia of language and linguistics (Vol. 3, pp. 1671-1678). Oxford: Pergamon.

Pounder, A. (2000). Processes and paradigms in word-formation morphology. Berlin \& New York, NY: de Gruyter.

Raffelsiefen, R. (1996). Gaps in word-formation. In U. Kleinhenz (Ed.), Interfaces in phonology (pp. 194-209). Berlin: Akademie Verlag.

Rainer, F. (1988). Towards a theory of blocking: the case of Italian and German quality nouns. In G. Booij \& J. van Marle (Eds.), Yearbook of Morphology 1998 (pp. 155-185). Dordrecht: Foris.

Rainer, F. (2012). Morphological metaphysics: virtual, potential, and actual words. Word Structure, 5(2), 165-182.

Rainer, F. (2016). Blocking. In Aronoff (Ed.), Oxford Research Encyclopedias: Linguistics. DOI: 10.1093/acrefore/9780199384655.013.33.

Roché, M. (2017a). Les familles dérivationnelles: comment ça marche? Toulouse: Université Toulouse 2 Jean Jaurès.

Roché, M. (2017b). Un exemple de réseau constructionnel: ethnique, toponymes, gentilés. Toulouse: Université Toulouse 2 Jean Jaurès.

Roché, M., \& Plénat, M. (2014). Le jeu des contraintes dans la sélection du thème présuffixal. In F. Neveu, P. Blumenthal, L. Hriba, A. Gerstenberg, J. Meinschaefer \& S. Prévost (Eds.), Proceedings of the $4^{e}$ Congrès Mondial de Linguistique Française (CMLF 2014) (Vol. 8, pp. 1863-1878). Paris: Institute de Linguistique Française. Dor: $10.1051 /$ shsconf $/ 20140801143$

Spencer, A. (2017). Participles: inflectional paradigms, derivational paradigms or something else? Paper delivered at ParadigMo 2017: First Workshop on Paradigmatic Word Formation Modeling, Toulouse, 19-20 June 2017.

Štekauer, P. (2005). Meaning predictability in word-formation: Novel, context-free naming units. Amsterdam, Philadelphia, PI: John Benjamins.

Štekauer, P. (2014). Derivational paradigms. In R. Lieber \& P. Štekauer (Eds.), The Oxford handbook of derivational morphology (pp. 354-369). Oxford: Oxford University Press.

Štekauer, P. (2015). Backformation. In P. O. Müller, I. Ohnheiser, S. Olsen \& F. Rainer (Eds.), Word-formation. An international handbook of the languages of Europe (pp. 340-351). Berlin, New York, NY: de Gruyter Mouton. 
Štekauer, P., Valera, S., \& Körtvélyessy, L. (2012). Word-formation in the world's languages. A typological survey. Cambridge: Cambridge University Press.

Stump, G. (1991). A paradigm-based theory of morphosemantic mismatches. Language, 67(4), 675-725.

Stump, G. (2018). Some sources of apparent gaps in derivational paradigms. Morphology, 1-31. DOI: 10.1007/s11525-018-9329-z [Accessed 24 September, 2018].

ten Hacken, P. (2014). Delineating derivation and inflection. In R. Lieber \& P. Štekauer

(Eds.), The Oxford handbook of derivational morphology (pp. 10-25). Oxford: Oxford University Press.

Thorne, T. (2014). Dictionary of contemporary slang. Bloomsbury Publishing. van Marle, J. (1985). On the paradigmatic dimension of morphological creativity. Dordrecht: Foris.

van Marle, J. (1994). Paradigms. In R. E. Asher (Ed.), Encyclopedia of language and linguistics (Vol. 6, pp. 2927-2930). Oxford: Pergamon.

Veselinova, L. N. (2006). Suppletion in verb paradigms. Bits and pieces of the puzzle. Amsterdam \& Philadelphia, PI: John Benjamins. 